Man and Nature

MAN AND NATURE

L'homme et la nature

L'HOMME ET LA NATURE

\title{
Jacques le fataliste: Narrative Structure and New Physics
}

\section{David Highnam}

Volume 2, 1984

URI : https://id.erudit.org/iderudit/1011808ar

DOI : https://doi.org/10.7202/1011808ar

Aller au sommaire du numéro

\section{Éditeur(s)}

Canadian Society for Eighteenth-Century Studies / Société canadienne d'étude du dix-huitième siècle

\section{ISSN}

0824-3298 (imprimé)

1927-8810 (numérique)

Découvrir la revue

Citer cet article

Highnam, D. (1984). Jacques le fataliste: Narrative Structure and New Physics. Man and Nature / L'homme et la nature, 2, 15-26.

https://doi.org/10.7202/1011808ar
Résumé de l'article

Jacques le fataliste peut être rapproché de certains aspects de la physique moderne, que ce soit par sa thématique de la relation indécidable entre pensée et réalité ou par sa structure mettant en jeu des oppositions binaires. La physique moderne a dû renoncer aux certitudes de l'ordre présumément objectif de l'univers newtonien. Depuis Heisenberg, elle fait valoir le principe de l'incertitude, les sauts discontinus de la théorie des quanta, l'impossibilité de décider de la description corpusculaire ou ondulatoire des phénomènes subatomiques, et surtout le rôle de l'observateur dans l'acte d'observation. Comme Zen, la physique moderne fait une grande place au paradoxe, ce qui permet d'établir des analogies aptes à jeter une nouvelle lumière sur le texte de Jacques le fataliste.
Copyright (C Canadian Society for Eighteenth-Century Studies / Sociéte canadienne d'étude du dix-huitième siècle, 1984
Ce document est protégé par la loi sur le droit d'auteur. L'utilisation des services d’Érudit (y compris la reproduction) est assujettie à sa politique d'utilisation que vous pouvez consulter en ligne.

https://apropos.erudit.org/fr/usagers/politique-dutilisation/ 


\section{JACQUES LE FATALISTE:}

NARRATIVE STRUCTURE AND NEW PHYSICS

David Highnam

There is perhaps no work of fiction in eighteenth-century French literature which has provoked more scholarly debate as to the principle of its structure and its ultimate "meaning" than Jacques le fataliste. 1 In 1975 , E. Walter affirmed that the absence of a critical edition of Jacques to that date was due to the unadmitted inability of scholars to determine the status of the text and to affix a meaning to it. ${ }^{2}$

According to Walter, two key questions had yet to find an answer, "what is Jacques le fataliste?" and "why is Jacques le fataliste?" Since these somewhat provocative assertions were put forth, we have seen the appearance of a critical edition of Jacques, 3 and we are still, of course, looking for those definitive answers. We can, nevertheless, affirm that since the ground-breaking work of Robert Loy's Diderot's Determined Fatalist in 1950, 4 there has been a growing number of ingenious and increasingly comprehensive attempts to answer the basic questions: how is Jacques put together and what does it mean?

I do not presume that the present study removes all doubt regarding the answers to these questions. If one has truly assimilated the lesson of the novel, one accepts that the critical enterprise is also a voyage where one must be satisfied with the traveling and put aside the notion of arriving at ultimate destinations.

At the present time, the most satisfying answer I have found to the question "what is Jacques?" is that by and through its constituent parts, Jacques is an essay on the nature of reality (and, by extension, the nature 
of truth) in which basic attitudes toward the way the world goes round are put to the test of experience.

The most obvious of these attitudes is the materialist thesis propounded by Jacques and represented by the figure of the "Grand Rouleau," according to which everything has been pre-determined by the overriding, immutable laws of nature. This definition of physical reality is supported by the laws of Newtonian physics. In opposition to this, the free-will thesis championed by the master affirms, as his title implies, that man is the master of his own destiny.

Popular "wish-fulfillment" attitudes as to the nature of reality are represented by the fictionalized reader who attempts to impart meaning to the text (and to reality) in the form of logical sequences of cause and effect. Questions such as "who?" "what?" "when?" "where?" "why?" seek to locate the characters and the events of the fiction in a temporal/causal sequence.

Each of these attitudes has its equivalent element in the perspective of the fictional structure: the "Grand Rouleau" is the historical truth (that which has already happened or must happen) which the novel purports to imitate; the free-will thesis corresponds to the creative liberty of the artist: the "wish-fulfillment" syndrome is the inspirational force behind all traditional fiction (what Diderot calls "contes d'amour").

The narrator of Jacques steers his course between these three points of the compass. On the one hand, he repeatedly affirms that he is resisting the temptation to "write a novel" and thus satisfy the wish-fulfillment of his fictional reader. At the other end of the spectrum, he affirms both implicitly and explicitly the truth of his narration in a number of ways:

1) He claims that his refusal to write a novel is proof of the veracity of his text, "... je n'aime pas les romans, à moins que ce ne soient ceux de Richardson. Je fais I'histoire; cette histoire intéressera ou n'intéressera pas, c'est le moindre de mes soucis. Mon projet est d'être vrai, je l'ai rempli."5

2) He mixes his own temporal plane with that of the fiction, both in the past by using his personal experience to corroborate the events of the fiction, and in the present by making the time of the narration coincide with the time of the events narrated and by mixing his own opinions and judgments with those of his characters.

3) He invokes the authority of the "Rouleau" as containing the only possible truth, the one he eventually chooses after having considered and rejected all the others as temptations, illusions, incorrect guesses.

4) Finally, as in example number three, he mocks the question altogether by pretending that he is following a manuscript.

The third option for the narrator to exercise is the most difficult to realize as a position independant of the other two. To exercise the third option, the author must both be creative without imitating the traditional 
novel and give a truthful picture of reality without limiting himself to "that which has already happened" (and is thus true) or in other words, "ce qui est écrit là-haut."

This third option of the author (to depict reality without restricting himself to truth defined as that which has already happened or must happen) is exercised not at the level of any of the stories told, but in the actual fabric of the telling itself. This is what Steven Werner means when he says that "the content of Jacques is a mock content." 6

It is here, when one begins to talk about "the fabric of the telling itself," that the uniqueness of the novel begins to emerge. The first and most obvious observation in this regard is that Diderot has done everything possible to disrupt the syntagmatic structure of his novel (the syntagmatic structure refers to the horizontal, linear development in time of the plot, accentuating logical causality) in favour of the paradigmatic structure, which is vertical, atemporal and simultaneous, and is composed of the recurring elements of similar nature, such as themes, symbols and techniques.

In order to bring the paradigmatic structure of the text into focus, one has to speak of "leitmotifs" or "lignes de force" or "thematic axes," to illustrate some of the various terms of reference which have been used in this regard. The most all-encompassing thematic axis in the text raises the question of the basic nature of mankind's reality: does man have the freedom to control his destiny, or is his fate predetermined by the universal laws of nature? This is the fatalism versus free-will question, and its ramifications extend throughout the text.

The free-will thesis implies effective choice exercised in a spatiotemporal framework to control one's destiny. Man is seen as moving through space (the voyage thus symbolizes the life cycle) in a linear fashion, set out in time. In other words, man can know where he is going and choose the causes which will bring him to his desired destination. The traditional concept of a narration as a story unfolding in time is also implied in the image of a trip toward a destination. In Jacques, a great number of the characters are either travelling or narrating stories or both.

The theme of control or lack of control is also present in the master/ servant dialectic; in the relationship between men and women; in the stories of characters who seek to control the destiny of others; in the relationship between the narrator and his characters, and between the narrator and his reader; in the debate around the legitimacy of moral judgements on human actions, in the discussion about the difficulty of effective communication between human beings, and so on.

The dialectic of opposing binary pairs is the central paradigm of the text. Every term, every distinction is created in order to meet its opposite, and both are correct: "Et les voilà embarqués dans une querelle interminable sur les femmes, l'un prétendant qu'elles étaient bonnes, l'autre méchantes, et ils avaient tous deux raison."7

The permanent inability (or might we say, the unbending refusal) of the text to decide which one of any two opposing terms represents Truth, or Reality, produces a feeling of standstill, of repetition, of paradox. All 
structures in the text which traditionally of fer the promise of a coherent, linear progression through time and space (such as a narration, a voyage or character development, for example) go nowhere, or go in circles. At the level of the content of the narration (the "énoncé"), this is shown in the persistence of paradox, the juxtaposed, discontinuous segments of plot development, the radically opposed judgements as to the moral significance of events, the interchangeability of characters, and so forth. At the level of the process of the narration (the "énonciation"), this is shown in the incessant interruptions, in the abrupt changes of narrative perspective, in the narrator's persistent reflexions on his narration which confuse the time of the stories narrated and the time of the narrating.

The allegory of the château, where Jacques and his master are supposed to have passed their third night, is a perfect symbolic expression of the dominant world view based on the universality of paradox which Diderot seeks to communicate in his novel--Jacques and his master didn't spend the night in the château, because they were already there before they went in, and they never left the château, because they were still there after they had gone out:

"Si vous insistez, je vous dirai qu'ils s'acheminèrent vers... Oui, pourquoi pas?... vers un château immense au frontispice duquel on lisait: "Je n'appartiens à personne et j'appartiens à tout le monde. Vous y étiez avant que d'y entrer, et vous y serez encore quand vous en sortirez."--Entrèrent-ils dans ce château?--Non, car l'inscription était fausse, ou ils y étaient avant que d'y entrer.--Mais du moins ils en sortirent?--Non, car l'inscription était fausse, ou ils y étaient encore quand ils en furent sortis. 8

The allegory of the château demonstrates the ultimate futility and even unreality of the notion of a choice of destiny understood as an ordered progression through time and space. In terms of the voyage, there is nowhere to go, only the going; in terms of communication or narration, there is nothing to say, only the saying.

Let us turn now to the second question, "why is Jacques like that?" The most satisfying field of exploration for a response to this question which I have found to date is that which is set forth in Steven Werner's study, Diderot's Chaotic Scroll: Narrative Art in Jacques le fataliste. 9 Werner situates Jacques at the end of an era characterized by the belief in the existence of the one definitive Truth and the search for the possession of that Truth through the compendium of all knowledge, the description of the One Reality. In Diderot's public career, the vehicle for this search was the Encyclopédie. In his private novel, the ultimate text of reality is the "Grand Rouleau," but it is now situated in a burlesque and ironic climate of relativism and decline of belief: the epic of knowledge has now become the mock epic of the inaccessible and unintelligeable "Grand Rouleau"--the total work which cannot be interpreted, the grand writing which repeats itself.10 For Werner, the novel is characterized by the aesthetic of death--stable form is a dream, accurate communication an impossibility. All life is a comic and ironical movement toward entropy (lack of form), death. He includes here the death of the novel. 
The death in Jacques le fataliste of one vision of reality makes way for the emergence of a new vision. It is precisely this new vision of reality which the novel implies--its structure and meaning--which is at the root of the critical dilemma surrounding the novel. We in the twentieth century have been and are still participating in a monumental process of death and rebirth with regard to our dominant conception of the structure of reality--one which has great relevance to our understanding of Jacques le fataliste. I am referring, of course, to the invalidation of the description of physical reality embodied in Newtonian physics, which was the dominant physics of Diderot's time, and the revolutionary redefinition of the appearance of physical reality which is emerging from the continuing discoveries of the new physics. "New physics" can be defined as the conjunction of relativity theory and quantum mechanics.11

Jacques le fataliste prefigures, in fact, most of the profoundly revolutionary discoveries of new physics.12 Newtonian physics affirms an objective, ordered physical reality which obeys permanent laws of nature. It assumes that matter is composed of basic building blocks (atoms) which occupy a specific point in three-dimensional space. The elaboration of the laws of nature is as simple as reducing matter to its most elementary particles, and then observing how they interact. The description of this process poses no problem for the Newtonian physicist--language is an adequate tool for describing reality. Amaury de Riencourt asserts, in fact, that for the traditional western philosopher or scientist, the symbolic reality of language has entirely replaced the immediate experience of physical reality:

The great problem of the objectifying mind/the mind of the western scientist/ is to preserve the sense of reality of the physical world of phenomena independently of the human observer, while being fully aware of the unreliability of sense-perception when it comes to discerning the true nature of the phenomenon. The analytical nature of logical thought destroys the integrity of the phenomenon by dissecting it and cutting it down to its basic components. What saves the reality of the phenomenal world, therefore, is not analytical reason but the logos, creative reason--that is, intuition geared to the rational faculty. The logos prevents Western thought from looking upon the phenomenal world as mere illusion--it has its degrees of reality and its existence is saved by this logos which creates the intellectual concept... Objectified reality is thus reduced to theoretical knowledge based on the interaction between observer and phenomenon observed. But the observer himself, the subject, must then be analyzed and objectivized; his participation in the phenomenal interaction must be neutralized in an effort to understand the objective reality of the phenomenon. 13

The objectivization of both observed phenomenon and subjective observor takes its most radical form in the materialist philosophy which Jacques professes, but does not consistently follow. This paradox demonstrates the failure of this philosophy to deal with experiential reality. The figure of the paradox, which is universal in Jacques, is perhaps the most effective way of demonstrating the inadequacy and incompleteness of any verbal description of reality when faced with the ineffable quality of the direct experience. 14 
In the world of sub-atomic physics, new physicists, like their Newtonian ancestors, are still pursuing particles, but in so doing, they have come face to face with a paradox which is the very foundation of the new description of physical reality to emerge from this science. Sub-atomic particles are not, it appears, strictly and simply particles; they are waves as well--and they are both of these things at the same time:

The best answer that physicists have so far is that "particles" are actually interactions between fields. A field, like a wave, is spread out over a much larger area than a particle (a particle is restricted to one point). A field, moreover, completely fills a given space, like the gravitational field of the earth fills all of the space immediately around it.

When two fields interact with each other they interact neither gradually nor at all their areas of contact. Rather, when two fields interact, they do it instantaneously and at one single point in space ("instantaneously and locally"). These instantaneous and local interactions are "particles." The continual creation and annihilation of particles at the subatomic level is the result of the continual interaction of different fields. 15

Zukav affirms that the proven truth of the particle-wave paradox may be the major contribution of new physics to Western thought in that it dramatically demonstrates the inadequacy of our thought patterns for describing reality. 16

The inadequacy of language to describe reality is one of the major themes of Jacques le fataliste. Writers on new physics frequently compare the "unresolvable" paradoxes raised by this branch of science (i.e. "how can a particle be a particle and a wave at the same time?") to the riddles of the Zen masters known as koans:

Paradoxes are common in Buddhist literature. Paradoxes are the places where our rational mind bumps into its own limitations. According to eastern philosophy in general, opposites, such as good-bad, beautiful-ugly, birth-death, and so on, are "false distinctions." One cannot exist without the other. They are mental structures which we have created. These self-made and self-maintained illusions are the sole cause of paradoxes. To escape the bonds of conceptual limitation is to hear the sound of one hand clapping.

Physics is replete with koans, i.e., "picture a massless particle." Is it a coincidence that Buddhists exploring "internal" reality a millennium ago and physicists exploring "external" reality a millennium later both discovered that "understanding" involves passing the barrier of the paradox? ${ }^{17}$

Diderot's allegory of the château is also in the spirit of the Zen koan. Such paradoxes are intentionally constructed to jolt the mind out of its familiar pattern of reasoning and to lift it to a new para-analytic level of understanding. 18 Even though Diderot's allegory is offered in a tongue-in-cheek manner, the question of the adequacy of language to describe experiential reality is at the very heart of the novel: "Jacques-...Dis la chose comme elle est:... Cela n'arrive peut-être pas deux fois 
en un jour dans toute une grande ville. Et celui qui vous écoute est-il mieux disposé que celui qui parle? Non. D'où il doit arriver que deux fois à peine en un jour dans toute une grande ville on soit entendu comme on dit." 19

Furthermore, this near impossibility of getting anywhere in story telling, in novel writing or in travelling is presented in the novel not as a catastrophe, but as an unavoidable aspect of the human condition; to think otherwise is to delude oneself: "Jacques-- ...Avec vos questions, nous aurons fait le tour du monde avant que d'avoir atteint la fin de mes amours. Le Maitre--Qu'importe, pourvu que tu parles et que je t'écoute? $\mathrm{Ne}$ sont-ce pas les deux points importants? Tu me grondes lorsque tu devrais me remercier." 20 In its most radical form, this predominance of the énonciation over the énonce results in the totally solipsistic discourse, where the pretense of "communication" disappears entirely: "Je vous ai dit, premièrement; or un premièrement, c'est annoncer au moins un secondement. Secondement donc... Ecoutez-moi, ne m'écoutez pas, je parlerai tout seul..."2l

Newtonian physics avoided the dilemma of paradox by envisioning the world as a grand machine that exists "out there," like the "Grand Rouleau," following its own chain of causality. This process can be observed and measured objectively, since it exists quite apart from man's mind. New physics has discovered, quite to the contrary, that at the level of subatomic physics, there is no such thing as an imperturbable machine which man can objectively measure and eventually "know." The Princeton physicist John Wheeler presents this idea in the following way:

Nothing is more important about the quantum principle than this, that it destroys the concept of the world as "sitting out there," with the observer safely separated from it by a 20 centimeter slab of plate glass. Even to observe so miniscule an object as an electron, he must shatter the glass. He must reach in. He must install his chosen measuring equipment. It is up to him to decide whether he shall measure position or momentum. To install the equipment to measure the one prevents and excludes his installing the equipment to measure the other. Moreover, the measurement changes the state of the electron. The universe will never afterwards be the same. To describe what has happened, one has to cross out that old world "observor" and put in its place the new word "participator." In some strange sense the universe is a participatory universe. 22

For the new physicist, in fact, material reality simply does not exist in any specific, particular, definitive way until he intervenes to measure it. Things in isolation have no characteristics--they have only tendencies to exist. Characteristics, or attributes, are the properties of interactions, not of things in isolation. Reality is a process, not a state. Seen in the terms of a literary critic, reality is an "énonciation," not an "énoncé." Jacques le fataliste is also a process of interactions, of collisions between opposing terms, and the reality it seeks to create is the property of none of the terms in isolation, but the product of the interaction. 
Another major discovery of new physics which can help us understand the structure of Jacques is that matter and energy are organized in quantums or specific units. This "quantized" structure, which is a universal characteristic of matter on the sub-atomic plane, means that matter does not flow continuously from one state to the next. If you excite electrons, for example, they do not move smoothly and continuously into larger orbits, they jump from one fixed orbit to the next, without occupying the space in between. No amount of measuring will ever find an electron outside of its fixed series of expanding or contracting orbits.

This brings up the obvious question of what happens to the electron while it is moving from one place to the next; does it cease to exist because it is not occupying a measurable point in space? The answer is that we don't know--language is inadequate to conceive let alone describe that aspect of reality. The best we can say is that the quantum nature of matter means that our illusion of the continuous nature of physical reality is precisely that, an illusion; and that reality is in truth composed of particles which exist in "contiguous discontinuity."

One could search indefinitely before finding a more apt description of the structure of Jacques le fataliste than the term "contiguous discontinuity": radical juxtapositioning of different spatial and temporal planes, multiple interruption of story lines, the predominance of paradigmatic axes, all of these are aspects of the contiguous discontinuity which reigns in this novel.

Furthermore, in the reality of new physics, particles can emerge from nothing, mutate and disappear again into the void, 23 just as doctors with girls riding double, bands of angry peasants and funeral processions appear and disappear in Jacques with no apparent origin and no known destination.

The most important discoveries of new physics lead inexorably to the conclusion that there is no distinction between consciousness and physical reality:

Philosophically, however, the implications of quantum mechanics are psychedelic. Not only do we influence our reality, but, in some degree, we actually create it. Because it is the nature of things that we can know either the momentum of a particle or its position, but not both, we must choose which of these two properties we want to determine. Metaphysically, this is very close to saying that we create certain properties because we choose to measure those properties. 24

This was formally acknowledged in 1927 with the Copenhagen Interpretation of quantum mechanics. In this document, the leading physicists of the day abandoned the attempt to devise a scientific description of physical reality based on a belief in the existence of some absolute, independant physical reality to which scientific theories correspond. The revolutionary aspect of such a statement is its implicit recognition that a complete understanding of reality lies beyond the capabilities of rational thought: "All that the mind can ponder is its ideas about reality. (Whether or not 
that is the way reality actually is, is a metaphysical issue.) Therefore, whether or not something is true is not a matter of how closely it corresponds to the absolute truth, but of how consistent it is with our experience." 25

To suggest that Jacques le fataliste is a deliberate fictional transposition of the principles of new physics is not the intention of this paper. It is more meaningful and no doubt more accurate to say that Diderot was simply exploring the gaps between theories of reality and experiences of reality. He was, in effect, giving free reign to the interplay of aspects of his own consciousness. He was allowing himself to portray events as they occur without the comforting context of the rational explanation, the historical perspective of cause and effect which makes their occurence understandable. He was attempting to capture some of the free play of consciousness below the rational level.

What is fascinating is that the disjointed, acausal, paradoxical image of reality which emerges from Diderot's novel is so analagous to the description of reality which is emerging from the new physics. This is amazing because of the thrust of creative imagination which this exercise would have required--in a general sense, considering the age was dominated by the orthodox physics of Newton, and in a personal sense, given Diderot's rational belief in the doctrine of materialism. Diderot has everywhere shown the need to externalize conflicting aspects of his own psyche, to explore the perimeters of the endless paradoxes which he experienced and observed around himself. The portrayal of paradox is perhaps Diderot's most familiar subject matter, but nowhere did he transcend the sense of stalemate which rises from paradox more effectively than in Jacques le fataliste.

The source of this sense of the transcendent lies first of all in the portrayal of the character of Jacques himself, the self-contradicting philosopher who sees his internal contradictions and chooses simply to exist: "... ferme comme un rocher dans les grandes occasions, il arrive souvent qu'une petite contradiction, une bagatelle me déferre, c'est à se donner des soufflets. J'y ai renoncé, j'ai pris le parti d'être comme je suis, et j'ai vu, en y pensant un peu, que cela revenait presque au même, en ajoutant qu'importe comme on soit?" 26 Jacques is the "sage parmi les fous," the philosopher who does not allow the flagrant contradictions which exist in his own thought and behaviour and in the world around him to bring the pace of life to a halt. The entire richly interwoven network of occurrences in the novel (philosophies, events, judgements, stories of triumph and of defeat, of honesty and dishonesty, of faithfulness and betrayal) leads neither to one overriding conclusion nor the other. These events are not emptied of their ability to move us, rather they are emptied of their value as proof of an overall interpretation of the meaning of existence. What remains is simply the unjudged and unqualified existence of these separate entities, experiences, events.

In his work A Rumor of Angels, 27 Peter Berger describes what he calls "signals of transcendence," which operate at all times and in all cultures. Signals of transcendence are modes of communication or behaviour which imply the existence of an order greater than the one which is normally discernable in ordinary reality. Two of the specific signals of 
transcendence which Berger identifies are humour and play. Signals of transcendence are not established by direct verbal reference, they are rather implied when one behaves as if he were in subconscious communication with a reality totally different from the "conventional" reality upon which we all supposedly concur. This very aptly describes Jacques' behaviour in the novel, where his constant mixture of passionate engagement and fatalistic resignation never interrupts his imperturbable pace of life, never costs him a night's sleep.

The image of reality which comes from Jacques le fataliste is also fascinating because it is composed on the one hand of scenes and events which are very convincing for their historical or psychological accuracy and on the other of scenes, events, characters which are willfully vague or exaggerated. "True" characters and fictional characters become hopelessly intermeshed; no single level of reality retains a stronger claim to authenticity than any other. "Reality," understood as an objectified realm having a special claim to authenticity (something like the definitive text of existence written on the "Grand Rouleau") ceases to have any meaning. Reality becomes a question of consciousness, and consciousness is the ultimate subjective domain.

Every aspect of new physics points us to the conclusion that consciousness is the only "reality" as we know it in the traditional sense--and even consciousness is a quantum process at its most fundamental level. Gary Zukav brilliantly illustrates this interconnected aspect of reality and consciousness in the following passage:

"Reality" is what we take to be true. What we take to be true is what we believe. What we believe is based upon our perceptions. What we perceive depends upon what we look for. What we look for depends upon what we perceive. What we perceive determines what we believe. What we believe determines what we take to be true. What we take to be true is our reality. 28

Consciousness in Jacques le fataliste is most obviously that of the narrator--more specifically, the narrator's consciousness of narrating. Taken one step further, we would say that Jacques is structured as a mirror --a mirror of consciousness. To begin with, a mirror of the narrator's consciousness of narrating, but ultimately, a mirror of the reader's consciousness. What the reader "sees" when he looks into Jacques is the mirror of his own consciousness.

Our dilemma as readers and critics of Jacques is the same as that of the sub-atomic physicist--as we break the glass and reach in to measure, understand, confer meaning, Jacques does not give us the ultimate meaning, the one true meaning (he who is looking for it is as obsolete as the Newtonian physicist). Jacques gives us the meaning we are looking for. 
Notes

1 In 1964, Robert Mauzi surveyed the variety of critical interpretations which Jacques had elicited in "La parodie romanesque dans Jacques le fataliste," Diderot Studies, 6 (1964), 89-132. Again in 1975, Eric Walter provides a survey of the critical approaches to the novel in Jacques le fataliste de Diderot, Ed. Poche Critique (Paris: Hachette, 1975).

Walter, p. 7 .

Denis Diderot, Jacques le fataliste et son maitre, Ed. critique par S. Lecointre et J. Le Galliot (Genève: Droz, 1977). All quotations from the novel will be taken from this edition.

J. Robert Loy, Diderot's Determined Fatalist (New York: Columbia University Press, 1950).

Ed. critique, p. 315 .

Stephen Werner, Diderot's Great Scroll: Narrative Art in Jacques le fataliste, SVEC, 128 (1975), 24.

Ed. critique, p. 28 .

Ed. critique, p. 29.

9 See note 6 .

10 Werner, p. 10.

11 Gary Zukav, The Dancing Wu Li Masters: An Overview of the New Physics (New York: Bantam, 1979), p. xxvii.

12 "Profoundly revolutionary" must be understood, of course, in the context of the dominant cultural ethos of Western man--an ethos which is based on his scientific definition of reality. There is nothing profoundly revolutionary about new physics from the point of view of the Tibetan monk, the Taoist philosopher or the student of Vedantan scripture.

13 Amaury de Riencourt, The Eye of Shiva: Eastern Mysticism and Science (New York: Morrow, 1981), pp. 100-101.

14 Most writers on new physics refer to this question. The following passage taken from Michael Talbot's Mysticism and the New Physics (New York: Bantam, 1981), p. 179, is one example among many: "There are two interesting points to be learned from the convergence of mysticism and new physics. The first is that the ultimate nature of reality transcends language... That is because language is based on discrimination." 
Zukav, p. 199.

16 "The major contribution of quantum mechanics to western thought, and there are many, may be its impact on the artificial categories by which we structure our perceptions, since ossified perceptions are the prisons in which we unknowingly become prisoners. Quantum theory boldly states that something can be this and that (a wave and a particle). It makes no sense to ask which of these is really the true description. Both of them are required for a complete understanding." Zukav, pp. 200-201.

17 Zukav, p. 205.

18 "Koans are carefully devised nonsensical riddles which are meant to make the student of Zen realize the limitations of logic and reasoning in the most dramatic way. The irrational wording and paradoxical content of these riddles makes it impossible to solve them by thinking. They are designed precisely to stop the thought process and thus to make the student ready for the non-verbal experience of reality." Fritjof Capra in The Tao of Physics (Berkeley: Shambhala, 1975), p. 48.

19 Ed. critique, pp. 70-71.

20 Ed. critique, p. 53.

21 Ed. critique, p. 87. This passage also constitutes a parody of the sequential logic of discourse.

22 Capra, p. 141.

23 "According to particle physics, the world is fundamentally dancing energy: energy that is everywhere and incessantly assuming first this form and then that. What we have been calling matter (particles) constantly is being created, annihilated and created again. This happens as particles interact and it also happens, literally, out of nowhere." Zukav, pp. 193-94.

24 Zukav, p. 28.

25 Zukav, p. 38 .

26 Ed. critique, pp. 109-110.

27 Peter L. Berger, A Rumor of Angels: Modern Society and the Rediscovery of the Supernatural (New York: Doubleday, 1969). 